\title{
口腔扁平上皮癌の治療期間別の予後因子の解析
}

\author{
木戸幸恵·野口誠・金城尚典・巣山達 \\ 久保田裕美・宮崎晃亘・米倉宣幸 $\cdot$ 小浜源郁
}

\section{Prognostic factors for survival according to treatment period in oral squamous cell carcinomas}

\author{
Yukie Kido - Makoto Noguchi $\cdot$ Hisanori Kinjyo $\cdot$ Tathuru Suyama \\ Hiromi Kubota $\cdot$ Akihiro Miyazaki $\cdot$ Noriyuki Yonekura $\cdot$ Geniku Kohama
}

\begin{abstract}
The purpose of this study was to assess changes in prognostic factors related to modification of surgical treatment on the basis of grade of tumor malignancy and to contribute to improved surgical treatment of patients with oral squamous cell carcinoma. Fourhundred three patients with oral squamous cell carcinoma treated by surgery were classified according to treatment period as follows: first period, 1976-1986; second period, 1987-1991; and third period, 1992-1997.

Three and 5 -year cumulative disease-specific survival rates according to treatment period were as follows: first period $(n=187), 78.6,76.3 \%$; second period $(n=113), 76.6,73.7 \%$; and third period $(n=103)$, $88.9,87.2 \%$. On univariate analysis of survival according to T, N, stage, growth pattern, and mode of invasion, significant differences $(\mathrm{P}<0.05)$ were found for all characteristics in the first and second periods, while in the third period no significant difference was found for growth pattern or mode of invasion.

Cox regression analysis of disease-specific survival identified the following as independent prognostic factors: mode of invasion $(1+2,3,4 \mathrm{C}+4 \mathrm{D})$, growth pattern (exophytic, endophytic), and $\mathrm{N}(0,1,2)$ in the first period, mode of invasion $(1-3,4 \mathrm{C}+4 \mathrm{D})$ and $\mathrm{N}(0,1,2+3)$ in the second period, and only $\mathrm{N}(0,1,2)$ in the third period.

Owing to the improved outcome for highly invasive carcinoma, the prognostic values during the third period differed from those during the first and second periods.
\end{abstract}

Key words: oral squamous cell carcinoma (口腔扁平上皮癌), surgical management (外科療法), prognostic factor (予後因子), treatment period（治療期間）

緒 言

口腔扁平上皮癌の治療成績は, 従来の放射線治療主体の 治療から, 積極的に外科療法が取り入れられ飛躍的に向上 してきた ${ }^{1 \sim 3)}$. 当科では1976年以降現在まで, 外科療法を 主体として口腔扁平上皮癌の治療を行ってきた 4,5$)$.この 間, 初期の治療成績を臨床病理学的に検討し, 生検組織の

\section{札幌医科大学医学部口腔外科学講座}

(主任 : 小浜源郁教授)

Department of Oral Surgery, Sapporo Medical University, School of Medicine

(Chief: Prof. Geniku Kohama)

受付日 : 平成 13 年 2 月 21 日
腫瘍宿主境界部における癌浸潤様式が予後を反映する悪 性度の指標としてきわめて有用であることを明らかにし た ${ }^{6 \sim 12)}$. そこで, これ以降は癌の進展度のみならず, 癌浸 潤様式を主な組織学的悪性度の所見として, 根治性と機能 温存の両面の成績向上を目的に治療法の改善を行い 4, 5，8), 最近ではかなり満足のいく成績が得られるようになってき $た^{13 \sim 17)}$.

本研究では当科で加療した口腔扁平上皮癌の悪性度を考 慮した治療法の成績を検討し, 治療期間別の予後因子の違 いを明らかにすることで,さらなる治療成績の向上に資す ることを目的とした。 


\section{対象および方法}

1976年 4 月から 1997 年 3 月までの過去 21 年間に札幌医科 大学医学部付属病院歯科口腔外科で外科療法によって加療 した口腔扁平上皮癌一次症例は 411 例であった。初回手術 後局所再発をきたしたが, 全身状態が悪いために救済治療 を行い得なかった症例は 5 例であった. 口腔内重複癌症例 で, 第一癌 (舌) および第二癌（上顎歯肉）は制御できた が, 第三癌 (煩粘膜) が原発巣非制御となり, 腫瘍死した症 例が 1 例, 頭頸部癌取り扱い規約 ${ }^{18)}$ による合併症死が 1 例, 死因不明が 1 例であった. 本研究では原発腫瘍の根治 手術例の予後因子を明らかにすることを目的としたため， これら 8 例は対象から除外し, 残りの403例を検討対象と した.

\section{1. 対象症例の性, 年齢別頻度}

性別は男性286例 (71.0\%), 女性117例 $(29.0 \%)$ で, 年齢 は26歳から 89 歳にわたり, 60歳台が121例と最も多く, 平均 年齢は 56.4 歳であった.

\section{2 . 原発部位別内訳}

舌が197例と最多でほぼ半数 $(48.9 \%)$ を占めていた。以 下,下顎歯肉 : 68例, 口底 : 68例, 類粘膜 : 33例, 上顎歯 肉 : 27 例, 口唇 : 10例であった。

\section{3 . 臨床病理学的所見別内訳}

UICC（1997年）による T, N, Stage 別内訳は T 1：108 例, T $2: 175$ 例, T $3: 49$ 例, T $4: 71$ 例, N $0: 265$ 例, N 1 : 89例, N $2: 48$ 例, N $3: 1$ 例, Stage I : 101例, II : 130例, III : 81例, IVA : 90例, IVB : 1例であった.なお, 歯肉癌の T 4 の解釈は, 下顎は藤林らの報告 ${ }^{19)}$ に基づき, 腫瘍の進 展が画像所見で，下顎管に及ぶものを T 4 とし，上顎では 画像所見で，上顎骨が破壊され上顎洞，鼻腔または外側皮 膚への進展が明らかなものを T 4 とした. 発育型（熟津分 類 $\left.{ }^{20)}\right)$ は外向型：178例, 内向型：225例であった. Histopathological grading (1997年, UICC, 以下, HG と略記) は, G $1:$ 183例, G $2: 170$ 例, G $3: 50$ 例で, 癌浸潤様式 ${ }^{10)}$ では 1 型：55例， 2 型：97例， 3 型：148例， $4 \mathrm{C}$ 型 : 65例，4D型：38例であった（表 1 ).

\section{4. 治療期間の分け方（表 1 )}

当科では口腔癌に対し, 1976年以降から現在まで外科療 法を主体とした治療を行っている。この間, 初期では手術 法の選択, 適用にあたり, 臨床所見 (TNM 分類, 発育型, X 線所見）を主な参考所見として,大きめな切除範囲を設定 していた。そして，この時期の retrospective study から，
癌浸潤様式を主体とした組織学的悪性度が, 臨床病期だ けでなく予後と関連する因子であることを明らかにし た ${ }^{4 \sim 12)}$. そこで, 以降は口腔機能の温存と優れた根治性を 得ることを目的に, 臨床所見と浸潤様式を主体とした悪性 度に基づいた切除範囲を設定した ${ }^{4)}$ 。さらに，最近ではそ れまでの治療概念に加えて, Stage I， II症例に対して, 積 極的に摘除生検 (excisional biopsy) ${ }^{21)}$ （以下, EB と略 記）と高悪性度癌の厳重な経過観察による潜在性リンパ節 転移の早期発見と早期の郭清を行った. 以上のように治療 法の改善を行ってきたため, 本研究では治療期間を第 1 期 （1976年 4 月～1987年 3 月），第 2 期（1987年 4 月～1992年 3 月), 第 3 期 (1992年 4 月〜1997年 3 月）に分けて各期間ご との治療成績ならびに予後因子の検討を行った.

\section{5 . 各期間別治療法の内訳}

第 1 期の $\mathrm{N} 0$ 症例 121 例に対する治療方法は, $\mathrm{EB}: 18$ 例 (14.9\%), 術前治療十原発巣切除 : 54 例 $(44.6 \%)$ であっ た. 術前治療に加え，原発巣切除と同時に頸部郭清術を 行った症例は 40 例 $(33.1 \%)$ であった.

第 2 期の $\mathrm{N} 0$ 症例 71 例に対する治療方法は, $\mathrm{EB}: 16$ 例 $(22.5 \%)$, 術前治療十原発巣切除 : 34 例 $(47.9 \%)$, 術前治 療十原発巣切除十頸部郭清術 : 14例 (19.7\%) であった。

第 3 期の $\mathrm{N} 0$ 症例 73例に対する治療方法は, $\mathrm{EB}: 33$ 例 $(45.2 \%)$, 術前治療十原発巣切除：25例 (34.3\%) であっ た. 術前治療十原発巣切除＋頸部郭清術：11例 (15.1\%) であった

切除生検 (incisional biopsy) ${ }^{21)}$ (以下, IB と略記) 後 に, 術前治療を行わず, 原発巣切除のみを行った症例およ び原発巣切除と頸部郭清術を行った症例は, 他の合併疾患 があり，化学療法を行えなかった症例で，いづれの期間に おいても, 少数例であった. 初診時頸部転移陽性例（N 1 〜 3 ) では全例に頸部郭清術が適応されていた（表 2 ).

これらの症例のうち, 術前療法として化学療法に加え放 射線療法を行った症例は第 1 期 : 7 例, 第 2 期 : 1 例, 第 3 期：12例であった. 放射線の線量は第 1，2 期：20４2 (平均30.75) Gy, 第 3 期 : 21-50 (平均40.1) Gy で, 照射時 期は第 1,2 期はすべて術前化学療法後であったのに対し, 第 3 期は術前化学療法後 : 6 例, CDDP（ $5 \mathrm{mg} /$ 回）の同 時併用療法：6例であった.

\section{6 . 治療成績および予後因子の解析}

治療成績は Kaplan Meier 法により，5年累積生存率 (overall survival および腫瘍死をエンドポイントとした disease specific survival) を求めた.また, 各治療期間ご とに T, N, Stage, 発育型, HG および癌浸潤様式別の 5 年 累積生存率は disesase specific survival を算出し, 生存率 
表 1 各期間における臨床病理所見の内訳

\begin{tabular}{|c|c|c|c|c|c|}
\hline & & & $\begin{array}{c}\text { 第 } 1 \text { 期 } \\
(1976 \text { 年 } 4 \text { 月 } \\
\sim 87 \text { 年 } 3 \text { 月 }) \\
n=187\end{array}$ & $\begin{array}{c}\text { 第 } 2 \text { 期 } \\
(87 \text { 年 } 4 \text { 月 } \\
\sim 92 \text { 年 } 3 \text { 月) } \\
\mathrm{n}=113\end{array}$ & $\begin{array}{c}\text { 第 } 3 \text { 期 } \\
\text { (92年 } 4 \text { 月 } \\
\sim 97 \text { 年 } 3 \text { 月) } \\
\mathrm{n}=103\end{array}$ \\
\hline 原発部位 & $\begin{array}{l}\text { 舌 } \\
\text { 下顎歯肉 } \\
\text { 口底 } \\
\text { 類 粘 膜 } \\
\text { 上顎歯肉 } \\
\text { 口唇 }\end{array}$ & $\begin{array}{l}(\mathrm{n}=197) \\
(\mathrm{n}=68) \\
(\mathrm{n}=68) \\
(\mathrm{n}=33) \\
(\mathrm{n}=27) \\
(\mathrm{n}=10)\end{array}$ & $\begin{array}{r}92 \\
37 \\
18 \\
20 \\
11 \\
9\end{array}$ & $\begin{array}{r}47 \\
19 \\
31 \\
5 \\
10 \\
1\end{array}$ & $\begin{array}{r}58 \\
12 \\
19 \\
8 \\
6 \\
0\end{array}$ \\
\hline $\mathrm{T}$ & $\begin{array}{l}1 \\
2 \\
3 \\
4\end{array}$ & $\begin{array}{l}(n=108) \\
(n=175) \\
(n=49) \\
(n=71)\end{array}$ & $\begin{array}{l}46 \\
81 \\
29 \\
31\end{array}$ & $\begin{array}{l}28 \\
48 \\
11 \\
26\end{array}$ & $\begin{array}{r}34 \\
46 \\
9 \\
14\end{array}$ \\
\hline $\mathrm{N}$ & $\begin{array}{l}0 \\
1 \\
2 \\
3\end{array}$ & $\begin{array}{l}(n=265) \\
(n=89) \\
(n=48) \\
(n=1)\end{array}$ & $\begin{array}{r}121 \\
49 \\
17 \\
0\end{array}$ & $\begin{array}{r}71 \\
25 \\
16 \\
1\end{array}$ & $\begin{array}{r}73 \\
15 \\
15 \\
0\end{array}$ \\
\hline Stage* & $\begin{array}{c}\text { I } \\
\text { II } \\
\text { III } \\
\text { IV A } \\
\text { IVB }\end{array}$ & $\begin{array}{l}(\mathrm{n}=101) \\
(\mathrm{n}=130) \\
(\mathrm{n}=81) \\
(\mathrm{n}=90) \\
(\mathrm{n}=1)\end{array}$ & $\begin{array}{r}45 \\
55 \\
48 \\
39 \\
0\end{array}$ & $\begin{array}{r}26 \\
40 \\
15 \\
31 \\
1\end{array}$ & $\begin{array}{r}30 \\
35 \\
18 \\
20 \\
0\end{array}$ \\
\hline 発育型 § & $\begin{array}{ll}\text { 外 } & \text { 向 } \\
\text { 内 } & \text { 向 }\end{array}$ & $\begin{array}{l}(n=178) \\
(n=225)\end{array}$ & $\begin{array}{l}98 \\
89\end{array}$ & $\begin{array}{l}45 \\
68\end{array}$ & $\begin{array}{l}35 \\
68\end{array}$ \\
\hline $\begin{array}{l}\text { Histopathological* } \\
\text { grading }\end{array}$ & $\begin{array}{l}\text { G } 1 \\
\text { G } 2 \\
\text { G } 3\end{array}$ & $\begin{array}{l}(n=183) \\
(n=170) \\
(n=50)\end{array}$ & $\begin{array}{l}72 \\
86 \\
29\end{array}$ & $\begin{array}{l}52 \\
49 \\
12\end{array}$ & $\begin{array}{r}59 \\
35 \\
9\end{array}$ \\
\hline 癌浸潤様式 ${ }^{\dagger}$ & $\begin{array}{c}1 \\
2 \\
3 \\
4 \mathrm{C} \\
4 \mathrm{D}\end{array}$ & $\begin{array}{l}(\mathrm{n}=55) \\
(\mathrm{n}=97) \\
(\mathrm{n}=148) \\
(\mathrm{n}=65) \\
(\mathrm{n}=38)\end{array}$ & $\begin{array}{l}33 \\
34 \\
66 \\
31 \\
23\end{array}$ & $\begin{array}{r}9 \\
38 \\
41 \\
19 \\
6\end{array}$ & $\begin{array}{r}13 \\
25 \\
41 \\
15 \\
9\end{array}$ \\
\hline
\end{tabular}

表 2 各期間別治療法の内訳

\begin{tabular}{|c|c|c|c|c|c|}
\hline & \multirow[b]{2}{*}{ 摘除生検（\%） } & \multicolumn{4}{|c|}{ 切除生検（\%） } \\
\hline & & 原発巣切除のみ & $\begin{array}{l}\text { 術前治療 } \\
+ \text { 原発宩切除 }\end{array}$ & $\begin{array}{l}\text { 原発巣切除 } \\
+ \text { +頸部郭清術 }\end{array}$ & $\begin{array}{l}\text { 術前治療 } \\
+ \text { 原発巣切除 } \\
+ \text { 頸部郭清術 }\end{array}$ \\
\hline 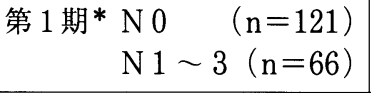 & $\begin{array}{c}18(14.9) \\
-\end{array}$ & $\begin{array}{c}8(6.6) \\
-\end{array}$ & $\begin{array}{c}54(44.6) \\
-\end{array}$ & $\begin{array}{c}1(0.8) \\
-\end{array}$ & $\begin{array}{l}40(33.1) \\
66(100)\end{array}$ \\
\hline 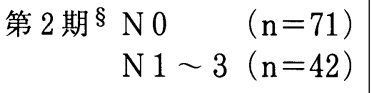 & $\begin{array}{c}16(22.5) \\
-\end{array}$ & $\begin{array}{c}6(8.5) \\
-\end{array}$ & $\begin{array}{c}34(47.9) \\
-\end{array}$ & $\begin{array}{ll}1 & (1.4) \\
1 & (2.4)\end{array}$ & $\begin{array}{l}14(19.7) \\
41(97.6)\end{array}$ \\
\hline $\begin{aligned} \text { 第 } 3 \text { 期 }^{\dagger} \text { N } 0 & (n=73) \\
N 1 \sim 3 & (n=30)\end{aligned}$ & $\begin{array}{c}33(45.2) \\
-\end{array}$ & $\begin{array}{c}3(4.1) \\
-\end{array}$ & $\begin{array}{c}25(34.3) \\
-\end{array}$ & $\begin{array}{c}1(1.4) \\
-\end{array}$ & $\begin{array}{l}11(15.1) \\
30(100)\end{array}$ \\
\hline
\end{tabular}



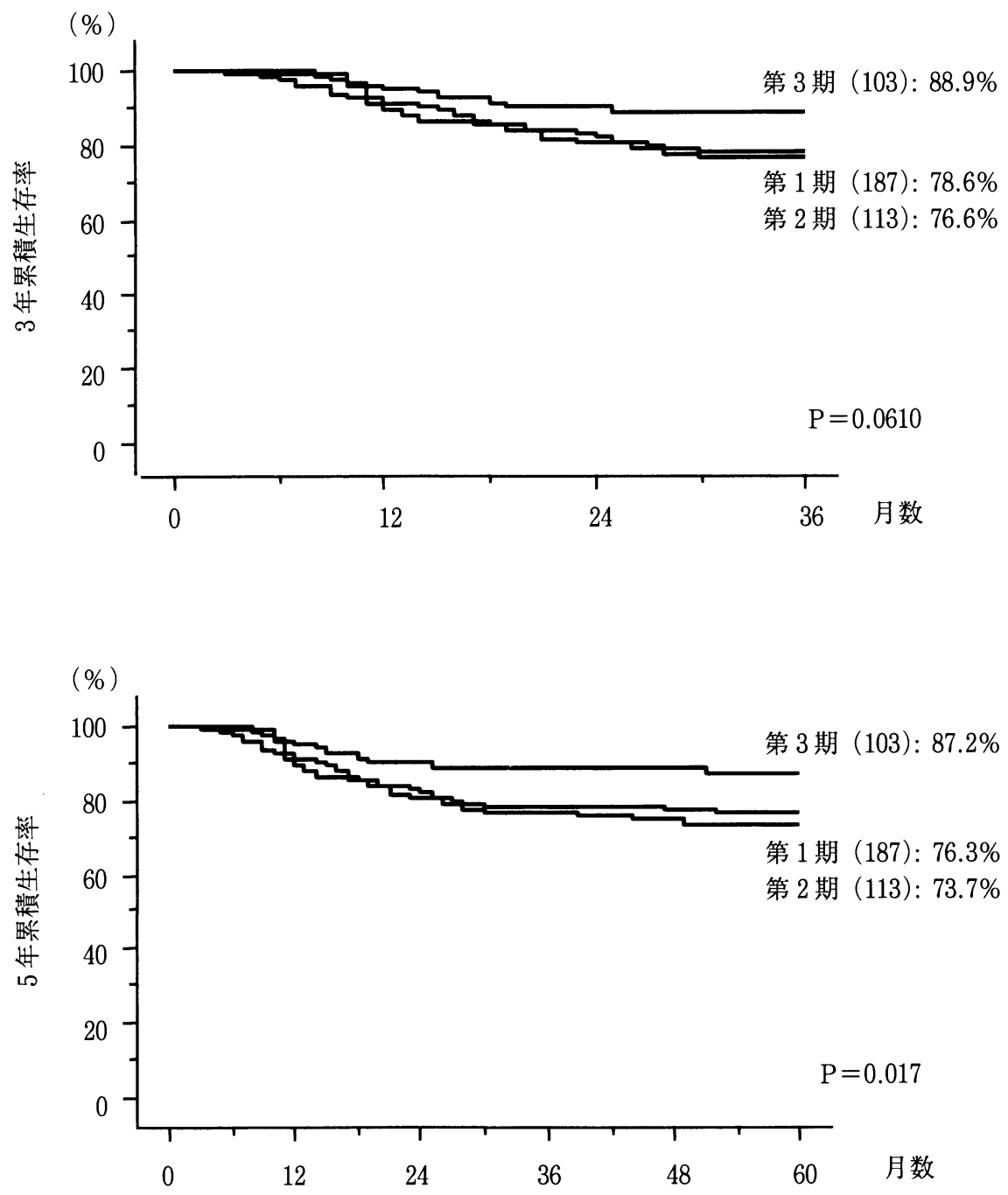

図 1 各期間別の治療成績

曲線の検定は logrank testにより行った.この生存曲線の 特徴を把握するために対数累積ハザード曲線の検討を行 い, おのおのの曲線がほぼ平行となるように各臨床病理学 的所見をサブグループに分類し，各期間別に Cox の比例ハ ザードモデルによる多変量解析を行った. 予後因子の選択 はstep wise methodによった. 統計解析は統計解析用ソ フト SAS Institute Inc., Stat view 5.0および SPSS INC., SPSS 6.1Jを用いて行った。なお, 生存最終経過観察日は 2000年 3 月 31 日とした.

\section{結果}

\section{1. 各期間の臨床病理学的所見別症例数}

各期間別の症例数を臨床病理学的所見別に表 1 に示す. 原発部位別症例数, 発育様式, HG, 癌浸潤様式別症例数に
カイ 2 乗検定にて有意差 $(\mathrm{p}<0.05)$ を認め, 症例分布に差 が認められた.一方, T, N, Stage 別では，各期間の症例分 布に差を認めなかった。

\section{2. 各期間別の治療成績}

対象403例の 5 年累積生存率は, overall survival rate : $71.7 \%$, disease specific survival rate : 78.2\%であった.

治療成績を治療期間別にみると，3 年，5 年累積生存率 (disease specific survival) は，それぞれ，第 1 期 : 78.6, $76.3 \%$ ，第 2 期 : 76.6, 73.7\%，第 3 期 : $88.9,87.2 \%$ で り，5年累積生存率曲線に統計学的有意差が認められた （図 1 ）. 以下に各治療期間ごとに T, N, Stage, 発育型, 浸 潤様式別の 5 年累積生存率 (disease specific survival) に ついて検討を行った.

$\mathrm{T}$ 分類別の 5 年累積生存率は, 第 1,2 期に比べ, 第 3 期 
表 3 臨床病理学的所見別の 5 年累積生存率

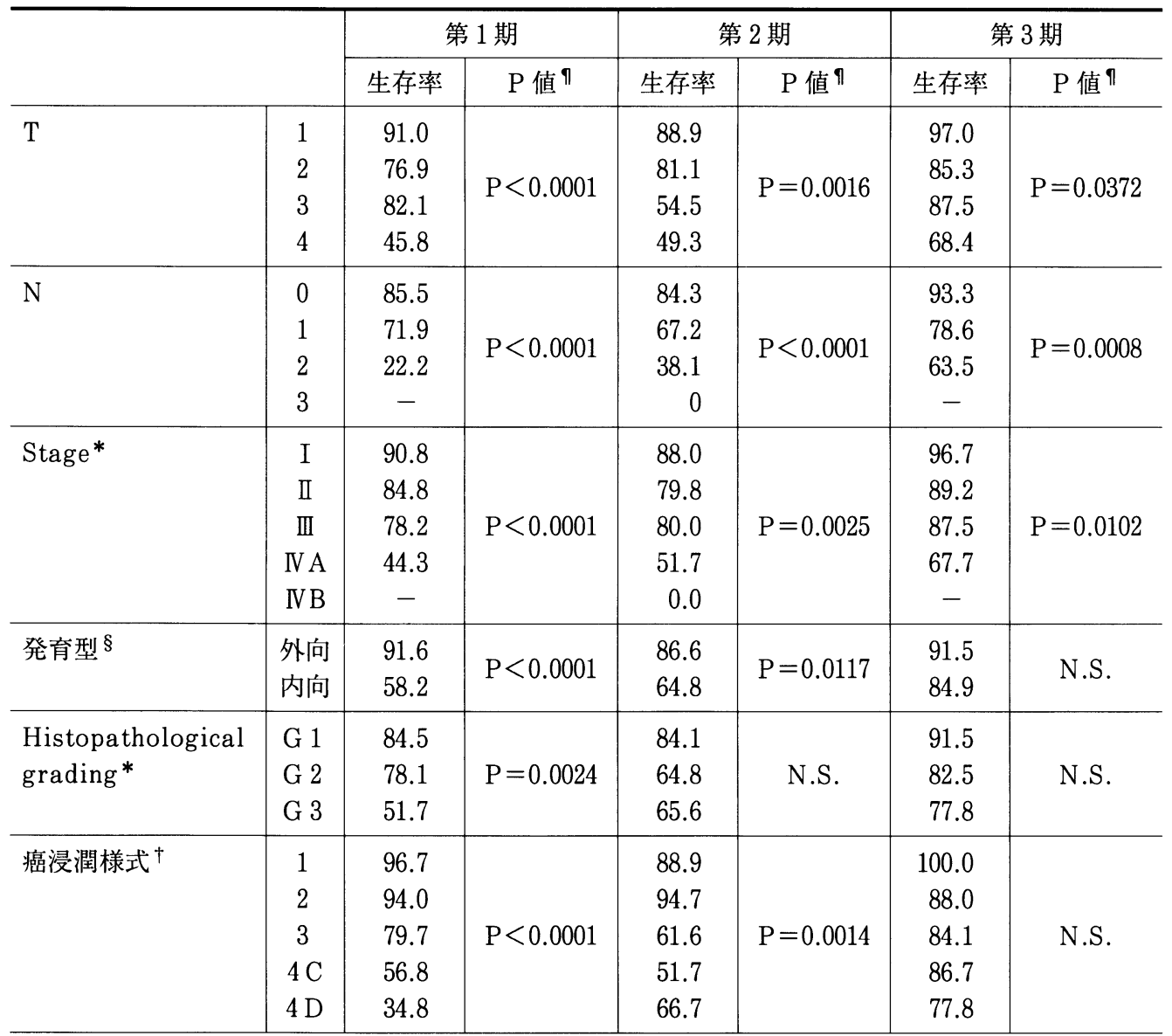

*: UICC, 1997年 $\S:$ 残津, 1973年 † : 山本, 小浜, 1983年

凤 : 生存率曲線の検定（logrank 検定）

において改善を認めた. なかでも，第 3 期における T 4 で は第 1 期の T 4 と比べると, 約 $20 \%$ の向上を認めた（表 3 ).

$\mathrm{N}$ 分類別では, 第 1,2 期では同様の結果であったが, 第 3 期において生存率は向上していた.

Stage 分類別では $\mathrm{N}$ 分類別の結果と同様で, 第 $1 ， 2$ 期 ではほぼ大差なく, 第 3 期では Stage I ～IVのすべての病 期で, 第 $1 ， 2$ 期の成績を上まわっていた。

各期間ごとの T, N, Stage 分類別の生存率曲線に危険率 $5 \%$ 以下で統計学的に有意差が認められた.

発育型別では, 外向型の生存率は全期間でほぼ同様に良 好であったが, 内向型では第 1 期 : $58.2 \%$, 第 2 期 : 64.8 $\%$, 第 3 期 : $84.9 \%$ と第 1 〜 期となるに従い生存率の向 上を認め, 発育型別の生存率の差が減少していた。第 1,2 期においては統計学的有意差を認めたが, 第 3 期において は外向型 : $91.5 \%$, 内向型 : 84.9\% と差が少なく, 有意差は 認めなかった.

HG 別では後期の症例ほど, G 3 の生存率の改善が認め
られた。

浸潤様式別では，1，2 型では全期間を通じて同様の結 果であり，3，4C 型では，第 1 期に比べ第 2 期でやや劣る 結果であったが, 第 3 期において 3 型 : $84.1 \%, 4 \mathrm{C}$ 型 : 8 $6.7 \%$ と良好であった. $4 \mathrm{D}$ 型の生存率は，第 1 期 : $34.8 \%$, 第 2 期 : $66.7 \%$, 第 3 期 : $77.8 \%$ と改善が認められた. 第 1 , 2 期では浸潤様式別の生存率曲線に統計学的有意差を認め たが, 第 3 期では認めなかった（表 3 ).

\section{3. 各期間別の $\operatorname{Cox}$ の比例ハザードモデルによる 多変量解析}

各期間ごとに T, N, Stage, 発育型, 浸潤様式別に対数累 積ハザード曲線の検討を行った. 第 1 期において T $1, \mathrm{~T} 2$ +3 , T 4 と subgroup に分類すると対数累積ハザード曲線 はほぼ平行となり, ハザード比が一定であることが確認さ れた.また， 5 年累積生存率は，T $1 （ \mathrm{n}=46): 91.0 \%, \mathrm{~T} 2$ $+3(\mathrm{n}=110): 78.3 \%, \mathrm{~T} 4(\mathrm{n}=31): 45.8 \%$ であった。 
表 4 subgroup の分類および 5 年累積生存率 : 第 1 期

\begin{tabular}{|c|c|c|c|c|}
\hline & subgroups & 症例数 & 生存率 & $\mathrm{P}$ 值 ๆ \\
\hline $\mathrm{T}$ & $\begin{array}{c}1 \\
2+3 \\
4\end{array}$ & $\begin{array}{r}46 \\
110 \\
31\end{array}$ & $\begin{array}{l}91.0 \\
78.3 \\
45.8\end{array}$ & $\mathrm{P}<0.0001$ \\
\hline $\mathrm{N}$ & $\begin{array}{l}0 \\
1 \\
2\end{array}$ & $\begin{array}{r}121 \\
49 \\
17\end{array}$ & $\begin{array}{l}85.5 \\
71.9 \\
22.2\end{array}$ & $\mathrm{P}<0.0001$ \\
\hline Stage* & $\begin{array}{l}\mathrm{I}+\mathrm{II} \\
\mathrm{III}+\mathrm{IV}\end{array}$ & $\begin{array}{r}100 \\
87\end{array}$ & $\begin{array}{l}87.5 \\
62.5\end{array}$ & $\mathrm{P}<0.0001$ \\
\hline 発育型 $§$ & $\begin{array}{l}\text { 外 向 } \\
\text { 内 向 }\end{array}$ & $\begin{array}{l}98 \\
89\end{array}$ & $\begin{array}{l}91.6 \\
58.2\end{array}$ & $\mathrm{P}<0.0001$ \\
\hline $\begin{array}{l}\text { Histopathological* } \\
\text { grading }\end{array}$ & $\begin{array}{c}1+2 \\
3\end{array}$ & $\begin{array}{r}158 \\
29\end{array}$ & $\begin{array}{l}81.0 \\
51.7\end{array}$ & $\mathrm{P}=0.0007$ \\
\hline 癌浸潤様式 ${ }^{\dagger}$ & $\begin{array}{c}1+2 \\
3 \\
4 \mathrm{C}+4 \mathrm{D}\end{array}$ & $\begin{array}{l}67 \\
66 \\
54\end{array}$ & $\begin{array}{l}96.8 \\
79.7 \\
47.2\end{array}$ & $\mathrm{P}<0.0001$ \\
\hline
\end{tabular}

*: UICC, 1997年 $\S:$ 粲津, 1973年 †: 山本, 小浜, 1983年

凤 : 生存率曲線の検定 (logrank 検定)

表 5 subgroup の分類および 5 年累積生存率 : 第 2 期

\begin{tabular}{c|c|c|c|c}
\hline & subgroups & 症例数 & 生存率 & $\mathrm{P}$ 值 \\
\hline $\mathrm{T}$ & 1,2 & 76 & 84.0 & $\mathrm{P}=0.0001$ \\
& 3,4 & 37 & 51.6 & \\
\hline $\mathrm{N}$ & 0 & 71 & 84.3 & $\mathrm{P}<0.0001$ \\
& 1 & 25 & 67.2 & \\
& 2,3 & 17 & 35.9 & \\
\hline Stage & $\mathrm{I} \sim \mathrm{II}$ & 81 & 82.5 & $\mathrm{P}=0.0002$ \\
& $\mathrm{IV}$ & 32 & 50.1 & \\
\hline 発育型 & 外 向 & 45 & 86.6 & $\mathrm{P}=0.0117$ \\
& 内 向 & 68 & 64.8 & \\
\hline Histopathological & 1 & 52 & 84.1 & $\mathrm{P}=0.0265$ \\
grading & $2+3$ & 61 & 65.0 & \\
\hline 癌浸潤様式 & $1 \sim 3$ & 88 & 79.0 & $\mathrm{P}=0.0095$ \\
& $4 \mathrm{C}, 4 \mathrm{D}$ & 25 & 55.5 & \\
\hline
\end{tabular}

*: UICC, 1997年 $\S:$ 䳑津, 1973年 †：山本, 小浜, 1983年

凤 : 生存率曲線の検定 (logrank 検定)

同様にしてN, Stage, 発育型, 浸潤様式別に subgroup に 分類し, 比例ハザード性の確認を行った（表 4 ）.さらに, 第 2,3 期についても同様に行った（表 5,6 ）.

各期間別に Cox の比例ハザードモデルによる多変量解 析を行った結果, step wise methodにより最終のモデルに 残った所見は, 第 1 期では浸潤様式 $(1+2,3,4 \mathrm{C}+4 \mathrm{D})$,
発育型 (外向, 内向), $\mathrm{N}(0,1,2)$, Stage $(\mathrm{I}+\mathrm{II}, \mathrm{II}+$ IV ) であった. そのうち, 統計学的に有意差を認めた所見 は浸潤様式, 発育型, $\mathrm{N}$ であった。

第 2 期では, 最終のモデルに残った所見は, 浸潤様式 ( 1 $\sim 3,4 \mathrm{C}+4 \mathrm{D}), \mathrm{N}(0,1,2+3)$, Stage ( I - III, IV ) で あった. そのうち, 統計学的に有意差を認めた所見は浸潤 
表 6 subgroup の分類および 5 年累積生存率 : 第 3 期

\begin{tabular}{|c|c|c|c|c|}
\hline & subgroups & 症例数 & 生存率 & $\mathrm{P}$ 值 \\
\hline $\mathrm{T}$ & $\begin{array}{c}1 \\
2,3 \\
4\end{array}$ & $\begin{array}{l}34 \\
55 \\
14\end{array}$ & $\begin{array}{l}97.0 \\
85.4 \\
68.4\end{array}$ & $\mathrm{P}=0.0145$ \\
\hline $\mathrm{N}$ & $\begin{array}{l}0 \\
1 \\
2\end{array}$ & $\begin{array}{l}73 \\
15 \\
15\end{array}$ & $\begin{array}{l}93.3 \\
78.6 \\
63.5\end{array}$ & $\mathrm{P}=0.0008$ \\
\hline Stage* & $\begin{array}{l}\mathrm{I} \sim \mathrm{III} \\
\mathrm{IV}\end{array}$ & $\begin{array}{l}83 \\
20\end{array}$ & $\begin{array}{l}91.5 \\
67.7\end{array}$ & $\mathrm{P}=0.0011$ \\
\hline 発育型 & $\begin{array}{l}\text { 外 向 } \\
\text { 内 向 }\end{array}$ & $\begin{array}{l}35 \\
68\end{array}$ & $\begin{array}{l}91.5 \\
84.9\end{array}$ & N.S. \\
\hline $\begin{array}{l}\text { Histopathological* } \\
\text { grading }\end{array}$ & $\begin{array}{l}1 \\
2 \\
3\end{array}$ & $\begin{array}{r}59 \\
35 \\
9 \\
\end{array}$ & $\begin{array}{l}91.5 \\
82.5 \\
77.8\end{array}$ & N.S. \\
\hline 癌浸潤様式 ${ }^{\dagger}$ & $\begin{array}{c}1 \sim 3 \\
4 \mathrm{C}, 4 \mathrm{D}\end{array}$ & $\begin{array}{l}79 \\
24\end{array}$ & $\begin{array}{l}88.2 \\
83.3\end{array}$ & N.S. \\
\hline
\end{tabular}

*: UICC, 1997年 $§:$ 鹋津, 1973年 †: 山本, 小浜, 1983年 凤：生存率曲線の検定（logrank 検定）

様式, $\mathrm{N}(0,1,2)$ であった. 第 3 期では予後因子として 選択された所見は $\mathrm{N}$ のみであり，第 $1 ， 2$ 期で予後因子と して選択された浸潤様式は生存に有意な影響を及ぼてい るとは判定されなかった（表 7 ). また, 各期の予後因子と しての重み（リスク比）は表 7 に示すごとくであった. 第 3 期では, 高悪性癌の治療成績の向上がみられ, 各期の予後 因子としての重みに相違が認められた。

\section{考察}

口腔癌の治療成績は15～30年前に比べ, 格段の向上が得 られている ${ }^{3,22,23)}$. 診断面においては CT, MRI, 超音波診 断法などによる画像診断技術の発達, 組織学的悪性度の評 価が，それに資している ${ }^{3}$, 15). また，一般の口腔癌に対す る認識が高まってきていることも一因で23), 早期癌が増加 した結果, 口腔癌全体の治癒率が向上したとする報告 $\left.{ }^{3}, 23\right)$ もみられる. 本研究においては各期間別の症例分布に差が みられた所見は, 部位, 発育様式, HG, 癌浸潤様式で, 癌の 進展度に差は認めなかった。

口腔癌の 5 年累積生存率は諸家ら 22 30)によると, 60.0 $71 \%$ と報告されている. 外科療法を主体に行った症例のみ を対象とした報告は少ないが，口峡咽頭の32例を含む口腔 癌200例の検討では, Woolgar ら ${ }^{31)}$ が $64 \%$ と報告している. 本研究では対象 403例の overall survival rate は71.7\%,
表 7 各期間別の COX の比例ハザードモデルによる多 変量解析

\begin{tabular}{|c|c|c|c|c|}
\hline & 因 子 & subgroups & リスク比 & $\mathrm{P}$ 値 \\
\hline \multirow{4}{*}{ 第 1 期 } & 浸潤様式 ${ }^{\dagger}$ & $\begin{array}{c}1+2 \\
3 \\
4 \mathrm{C}+4 \mathrm{D}\end{array}$ & $\begin{array}{l}1.000 \\
4.190 \\
10.076\end{array}$ & $\begin{array}{c}- \\
0.0663 \\
0.0033\end{array}$ \\
\hline & 発育型 $§$ & $\begin{array}{l}\text { 外向 } \\
\text { 内向 }\end{array}$ & $\begin{array}{l}1.000 \\
2.416\end{array}$ & $\begin{array}{c}- \\
0.0432\end{array}$ \\
\hline & $\mathrm{N}$ & $\begin{array}{l}0 \\
1 \\
2\end{array}$ & $\begin{array}{l}1.000 \\
0.785 \\
3.122\end{array}$ & $\begin{array}{c}- \\
0.6483 \\
0.0345\end{array}$ \\
\hline & Stage* & $\begin{array}{l}I+I I \\
I I I+I V\end{array}$ & $\begin{array}{l}1.000 \\
1.693\end{array}$ & $\begin{array}{c}- \\
0.3262\end{array}$ \\
\hline \multirow{3}{*}{ 第 2 期 } & 浸潤様式 ${ }^{\dagger}$ & $\begin{array}{c}1 \sim 3 \\
4 \mathrm{C}+4 \mathrm{D}\end{array}$ & $\begin{array}{l}1.000 \\
2.973\end{array}$ & $\begin{array}{c}- \\
0.0086\end{array}$ \\
\hline & $\mathrm{N}$ & $\begin{array}{c}0 \\
1 \\
2+3\end{array}$ & $\begin{array}{l}1.000 \\
1.395 \\
4.445\end{array}$ & $\begin{array}{c}- \\
0.5489 \\
0.0359\end{array}$ \\
\hline & Stage* & $\begin{array}{c}\mathrm{I}-\mathrm{III} \\
\mathrm{IV}\end{array}$ & $\begin{array}{l}1.000 \\
1.628\end{array}$ & $\begin{array}{c}- \\
0.4182\end{array}$ \\
\hline 第 3 期 & $\mathrm{N}$ & $\begin{array}{l}0 \\
1 \\
2\end{array}$ & $\begin{array}{c}1.000 \\
3.551 \\
8.722\end{array}$ & $\begin{array}{c}- \\
0.0971 \\
0.0013\end{array}$ \\
\hline
\end{tabular}


disease specific survival rateは78.2\%であり，良好で あった。

治療期間別に治療成績をみると，第 $1 ， 2$ 期に比べて， 1992年度以降の第 3 期では治療成績の向上を認めた。当 科では, 過去の治療成績を顧みて, 治療法の改善を行っ てきている. 1976年〜1986年の第 1 期の治療成績の検 討 $6,7,9 \sim 12)$ から, 臨床所見のみならず, 組織学的所見が癌 の性状を把握する上で重要であることを明らかにした。す なわち, 砂川 ${ }^{6)}$, 小浜 ${ }^{7)}$ は生検組織の組織学的所見に基 づく組織学的悪性度が BLM 制癌効果および予後と関連が あることを示し, 癌の臨床病期のみならず, 組織学的悪性 度を参考にすることで, 個々の症例に見合った療法選択が 可能となることを示唆した.

さらに, 山本ら ${ }^{9 \sim 12)}$ は, 生検組織の各組織所見の中で癌 浸潤様式が予後と密接に関連し, 特に，4 C, $4 \mathrm{D}$ 型の高度 浸潤癌は再発率, 転移率ともに高く, 予後不良であること を明らかにした。これらの結果をふまえ, 1987年以降の第 2 期は癌の進展度に加え, 癌浸潤様式を中心とした組織学的 悪性度を参考にして個々の症例に見合った手術法を適用す ることで, 高度浸潤性癌の根治性の向上と, 低悪性度癌に 対する機能温存の可能性を示唆した $\left.{ }^{4}, 5,13 \sim 15\right)$.

一方，この間に浸潤様式 $4 \mathrm{C} ， 4 \mathrm{D}$ 型といった高度浸潤性 癌の治療経験が集積されていった. 本研究で示されたよう に, 高度浸潤性癌の治療成績は第 1 期と比較して第 2 期で は改善傾向がみられたものの, 十分満足のいく成績とはい えなかった. そこで, 第 3 期では高度浸潤性癌の細胞特性 を考慮し, IBによる細胞播種ならびに転移の助長の可能性 を予防する目的から, 視診, 触診によって全体像の把握が 可能な小病変に対して $\mathrm{EB}$ を適用した ${ }^{16,17)}$. $\mathrm{EB}$ の適用に 当たっては, 腫瘍辺縁から約 $5 \sim 10 \mathrm{~mm}$ 程度離れた周囲健 康粘膜に surgical margin を設定し, 局所切除をおこなっ た. 内向型の発育様式を示す病変では, 深部の切除量を十 分とるようにした. 第 3 期において $\mathrm{EB}$ の適用により治療 成績が向上した理由としては, 浸潤様式 $4 \mathrm{C}, 4 \mathrm{D}$ の高度浸 潤性癌は再発, 転移をきたしやすく, 化学療法無効例が多 い32）という特性を勘案すると, IBによる癌細胞の播種と 転移の防止ができた可能性や，このような化学療法の無効 症例に対する無益な化学療法を施行せず, 治療が早めに行 われたことが考えられた.さらに，原発巣の所見から後発 転移を起こす確率の高い症例を予測し $33 \sim 35)$, そのような症 例に対し, 厳重な経過観察を行ったこと, 画像診断の進歩 も相まって, 後発転移の早期発見と早期治療が可能になっ たことも成績向上の要因と思われた.

各症例に見合った適切な治療法を適用するために予後因 子の検討は重要である ${ }^{36)}$. 多数例を扱った口腔癌の予後 因子に関する検討は，DÖSAKの一連の研究にみられ
る ${ }^{37 \sim 40)}$. その中で述べられているごとく, 予後因子を検討 する上で治療法は欠かすことのできない重要な因子である 38). したがって, 一定の治療法の下に加療された対象のみ を解析することによって，より実用的な子後因子が明らか になると思われる. 本研究では, 根治療法として外科療法 を適用した症例のみを検討対象とした. 他に多数例の外科 治療例のみを検討対象とし, 多変量解析にて予後因子を 検索した研究は数少なく, Beenken $ら^{41)}$, Hiratsuka $5^{35)}$,

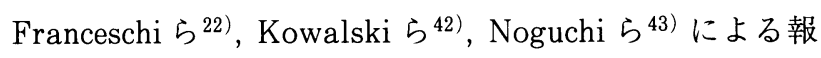
告が散見される.

Franceschi ら ${ }^{22)}$ は舌癌の予後因子として, Stage, 2 個 以上のリンパ節転移, 年齢, 局所再発であると報告し, Kowalski ら ${ }^{42)}$ は口腔癌の予後因子を検討し, リンパ節転 移のレベルが最も強力な予後因子であり，以下，性， T 分 類, 転移リンパ節の可動性, 年齢, 腫瘍の厚みであると報告 している. Noguchi ら ${ }^{43)}$ は当科における口腔癌 N $1 \sim 3$ 症 例の予後因子に関する検討で, 独立性の高い因子として選 択されたのは, $1 . \mathrm{pN}$ 分類, $2 . \mathrm{N}$ 分類, $3 . \mathrm{T}$ 分類, 4. 組 織学的悪性度で, 組織学的に転移を認めた症例では予後因 子は 1 ). 節外型リンパ節転移の有無, 2 ). $\mathrm{T}$ 分類であるこ とを報告した. 頸部リンパ節転移の有無および $\mathrm{N}$ 分類が重 要な予後因子であることは明白であり，今回の検討でも， $\mathrm{N}$ 分類は全期間において重要な子後因子であり，N 0 症例 と比べた N 2 のリスク比は, 第 1 期では 3.122 , 第 2 期では 4.445 , 第 3 期では8.722であった. 第 3 期においてリスク比 の増加が認められたのは, それ以前の予後因子が第 3 期で は予後因子としては現れなかったためであり，現に第 3 期 では N $0 \sim \mathrm{N} 2$ の生存率は一様に向上を認めている.また， 本研究結果では第 3 期において浸潤様式 $3,4 \mathrm{C}, 4 \mathrm{D}$ 型の 治療成績の向上を認め，さらに各期間別の Cox の比例ハ ザードモデルによる多変量解析にて癌浸潤様式が第 1,2 期では独立性の高い子後因子として選択されたが，第 3 期 においては予後因子としては選択されなかった．高度浸潤 癌に対する治療法改善が成績の向上につながったためと考 えられる.一方, 第 3 期において治療成績が劣っていたの はT 4, N 2, Stage IVAの症例であった.

以上の結果より, 現在の高悪性度癌に対する治療方針を もって治療を行えば, Stage I〜IIIの症例では根治性と機 能温存の面から，おおむね良好な成績が得られ，今後は Stage IVの高度進展例への対策が課題であることが明かと なった。

\section{結語}

外科療法を行った口腔粘膜癌403例を対象に第 1 期（1976 ～1986年），第 2 期（1987～1991年），第 3 期（1992１996 
年) の三期に分けて予後因子について検討を行い以下の結 果を得た。

1 ) 治療期間別の 3 年, 5 年累積生存率 (disease specific survival）は，それぞれ，第 1 期 $(n=187): 78.6,76.3 \%$, 第 2 期 $(n=113): 76.6,73.7 \%$, 第 3 期 $(n=103): 88.9$, $87.4 \%$ であり，第 3 期において治療成績の向上を認めた.

2 ) 各期間ごとに T, N, Stage, 発育型, 浸潤様式別 5 年 累積生存率をみると, T, N, Stage 別ではすべての期間に おいて生存率曲線に有意差 $(\mathrm{p}<0.05)$ を認めた。第 1,2 期の発育型別, 浸潤様式別では有意差 $(p<0.05)$ を認めた が, 第 3 期では有意差を認めなかった.

3 ) Cox の比例ハザードモデルによる多変量解析の結 果, 予後因子として選択された所見は第一期では浸潤様式 $(1+2,3,4 \mathrm{C}+4 \mathrm{D})$, 発育型 (外向, 内向), $\mathrm{N}(0,1,2)$ で, 第 2 期では浸潤様式 $(1 \sim 3,4 \mathrm{C}+4 \mathrm{D}), \mathrm{N}(0,1$, $2+3)$ で, 第 3 期では予後因子として選択された所見は $\mathrm{N}(0,1,2)$ であった.

第 3 期では, 高悪性癌の治療成績の向上が認められ, 各期 の予後因子としての重みに相違が認められた.

謝辞

統計学的解析について御助言, 御教示いただいた本学公衆 衛生学講座, 園田智子博士に深謝いたします.

\section{引用 文 献}

1）山本悦秀：癌腫（1）扁平上皮癌（舌，口底，煩粘 膜). 道 健一, 天笠光雄編 ; 口腔顎顔面外科治療 学. 第 1 版, 永末書店, 京都市, 1996, 193-202頁

2）山本悦秀：口腔の癌一特にその早期臨床像につい て一.金大開放センター紀要 13: 57-70 1993.

3）塩田重利：口腔癌の診断と治療の変遷。口病誌 58 : 1 - 7 1991

4）小浜源郁：口腔癌の臨床病期（Stage）別組織学的 悪性度（grade）からみた術前化学療法と外科療法。 清水正嗣，小浜源郁編；口腔癌。第 1 版，デンタル ダイヤモンド社, 東京, 1989, 204-211頁

5）山本悦秀, 小浜源郁：口腔癌の進展と悪性度からみ た手術基準.癌と化学療法 15: 1171-1177 1988.

6）砂川 元，山本悦秀：口腔領域の扁平上皮癌に関す る臨床病理学的検討一特にBleomycin 制癌効果の 計量的解析一. 札医誌 52: 531-557 1983

7）小浜源郁：口腔癌の化学療法効果に関する臨床, 病 理, 細胞性免疫学的研究一特に臨床病理学的悪性度 とブレオマイシン効果および予後についてー。科 誌 33: 672-698 1984 .

8）小浜源郁：舌癌一診断と外科療法. 日口外誌 35 1710-1714 1989 .

9）山本悦秀, 砂川 元, 他 : び漫性浸潤型口腔扁平上 皮癌に関する研究. 日口外誌 28: 1471-1479 1982

10) Yamamoto, E., Sunagawa, H., et al.: Clinical course of diffuse invasive carcinoma of the tongue excised after bleomycin treatment. J Maxillofac Surg 11: 269-274 1983.

11）山本悦秀, 小浜源郁, 他：原発巣切除後, 局所再発 なく後発転移をきたした非進展舌癌の検討一とくに 腫瘍の浸潤様式との関連について一。日口外誌 30 : 823-831 1984.

12）山本悦秀, 宮川 明, 他：口腔粘膜癌の所属リンパ 節内浸潤増殖像に関する研究. 一特に原発巣の腫瘍 の浸潤様式との関連について一. 日口外誌 30: 182418331984.

13）木戸幸恵, 野口 誠, 他：口底癌の外科療法と治療 成績. 頭頸部腫瘍 21: 99-104 1995.

14）野口 誠, 久保田裕美, 他：上顎歯肉癌の術前化学 療法と外科治療成績. 口腔腫瘍 9:307-313 1997.

15）野口誠, 宮崎晃亘, 他：口底癌の進展と悪性度に 基づく切除法と治療成績．頭頸部腫瘍 26：23-28 2000.

16）野口誠, 小浜源郁, 他：Excisional biopsy を 行った舌癌の治療成績一とくに癌浸潤様式との関連 についてー. 日口外誌 41: 515-519 1995

17）野口 誠, 仲盛健治, 他：高度浸潤性口腔癌の治療 に関する検討一Stage I ，II舌癌について一。腔 腫場 8: 1 - 71996.

18）日本頭頸部腫瘍学会編：臨床・病理 頭頸部癌取り 扱い規約. 改訂第 2 版, 金原出版, 東京, 1991，5-6 頁.

19）藤林孝司, 神田重信, 他：下顎管分類の妥当性一下 顎歯肉癌 $\mathrm{T}$ 分類全国集計結果から一. 医 - 歯薬研究 4: 20-20 1996.

20）鷲津邦雄，鈴木 邦：口腔癌の早期診断について 一特に臨床像を中心として一。日本歯科評論 372 : 13-22 1973.

21）日本癌治療学会編：日本癌治療学会・癌規約総論. 第 1 版, 金原出版, 東京, 1991, 60-70頁.

22) Franceschi, D., Gupta, R., et al.: Improved survival in the management of squamous carcinoma of the oral tongue. Am J Surg 166: 360-365 1993.

23）今谷哲也, 高森康次, 他：舌扁平上皮癌96例の臨床 統計的検討一治療法および治療成績の変遷.日口外 誌 43: 908-911 1996.

24）美馬孝至, 浦出雅裕, 他：当科における過去 9 年間 の悪性腫瘍の臨床統計的観察一特に口腔および上顎 洞扁平上皮癌症例について．日口外誌 34: 349-356 1988.

25）下里常弘, 伊達岡陽一, 他：当科における悪性腫瘍 の臨床統計的検討. 日口外誌 34: 2419-2429 1988.

26）田川俊郎, 平野吉雄, 他：当教室における過去 11 年 間の悪性腫瘍についての臨床統計的観察.日口外誌 35: 1428-1435 1989 .

27）西岡博人, 桐田忠昭, 他：当科における過去 10 年間 （1981～1991年）の顎・目腔領域悪性腫瘍症例の臨 床統計的観察. 奈医誌 45: 16-22 1994.

28）金沢春幸, 谷本良司, 他：口腔癌の臨床統計一口腔 癌の臨床統計一教室過去 10 年間の治療成績．日口外 誌 36: 2509-2517 1990 
29）宋 時澤, 佐藤 敦, 他: 当科開設以来 15 年間の口 腔扁平上皮癌の治療成績. 日口外誌 41: 1068-1070 1995.

30）川崎五郎, 高野美貴子, 他 : 舌扁平上皮癌症例の臨 床病理学的検討. 口科誌 46: 171-176 1997 .

31) Woolgar, JA., Rogers, S., et al.: Survival and patterns of recurrence in 200 oral cancer patients treated by radical surgery and neck dissection. Oral oncol 35: 257-265 1999.

32）金城尚典, 野口 誠, 他 : 核 DNA 量の画像解析法 を用いた口腔癌の術前化学療法効果の評価. 札医誌 69: 45-54 2000 .

33）宮川 明, 平塚博義, 他 : 口腔癌の潜在性頸部リン パ節転移に関する臨床的, 病理組織学的研究. 札医 誌 62: 43-53 1993.

34）平塚博義, 小浜源郁, 他 : 原発巣のみ切除を行った 口腔粘膜癌の後発転移に関する検討. 頭頸部腫瘍 21: 85-92 1995.

35) Hiratsuka, H., Miyakawa, A., et al.: Multivariate analysis of occult lymph node metastasis as a prognostic indicator for patients with squamous cell carcinoma of the oral cavity. Cancer 80: 351-356 1997.

36) Bundgaard, T., Bentzen, M., et al.: Histopathologic, stereologic, epidemiologic, and clinical parameters in the prognostic evaluation of squamous cell carcinoma of the oral cavity. Head Neck 18: 142-152 1996.

37) Fries, R., Platz, H., et al.: Carcinoma of the oral cavity: on the prognostic significance of the primary tumour site (by organs) in the oral cavity. J Maxillofac surg 8: 25-37 1980.

38) Platz, H., Fries, R., et al.: Carcinomas of the oral cavity: analysis of various pretherapeutic classifications. Head Neck Surg. 5: 93-107 1982.

39) Platz, H., Fries, R., et al.: The prognostic relevance of various factors at the time of the first admission of the patient. Retrospective DÖSAK study on the carcinoma of the oral cavity. J Maxillofac surg 11: 3 -12 1983.

40) Platz, H., Fries, R., et al.: Retrospective DÖSAK study on carcinomas of the oral cavity: results and consequences. J Maxillofac surg 13: 147-153 1985.

41) Beenken, S.W., Krontiras, H., et al.: T 1 and T 2 squamous cell carcinoma of the oral tongue: prognostic factors and the role of elective lymph node dissection. Head Neck 21: 124-130 1999.

42) Kowalski, L., Bagietto, R., et. al: Prognostic significance of the distribution of neck node metastasis from oral carcinoma. Head Neck 22: 207-214 2000.

43) Noguchi, M., Kido, Y., et al.: Prognostic factors and relative risk for survival in $\mathrm{N} 1-3$ oral squamous cell carcinoma: a multivariate analysis using Cox's hazard model. Br J Oral Maxillofac Surg 37: 433-437 1999. 